\title{
Uji Fisik Kimia dan Sensori Kerupuk Ikan Tembang (Sardinella sp.) dengan Subtitusi Tepung Ubi Jalar Putih (Ipomea batatas L.)
}

Physico-chemical and sensory analisis of sardinella (Sardinella sp.) crackers with substitution of white sweet potato (Ipomea batatas L.)

\author{
Sukma $^{1 *}$, Hermanto ${ }^{2}$, Suwarjoyowirayatno ${ }^{1}$ \\ 1Jurusan Teknologi Hasil Perikanan, Fakultas Perikanan dan Ilmu Kelautan Universitas Halu Oleo, Kendari, \\ Sulawesi Tenggara, Indonesia \\ 2Jurusan IImu dan Teknologi Pangan, Fakultas Pertanian Universitas Halu Oleo, Kendari, Sulawesi Tenggara, \\ Indonesia \\ *Email korespondensi: sukmashanna14@gmail.com (Telp: +6282293209522) \\ Diterima: 2 Oktober 2019/ Disetujui 18 November 2019
}

Cara sitasi: Sukma, Hermanto, Suwarjoyowirayatno. 2019. Uji fisik kimia dan sensori kerupuk ikan tembang (Sardinella sp.) dengan subtitusi tepung ubi jalar putih (Ipomea batatas L.). Jurnal Fish Protech. 2(2):260-266.

\section{ABSTRACT}

The aims of this study was to determine the effect of the addition of tembang fish meat (Sardinella sp.) And white potato flour (Ipomea batatas L.) substitution on the chemical and sensory physical tests of tembang fish crackers. This study used a Completely Randomized Design (CRD) consisting of three treatments, namely S1 (DI 25\%: 0\% TUJ: 75\% TT), S2 (DI 25\%: 5\% TUJ: 70\% TT), S3 (DI $25 \%$ : TUJ 10\%: TT 65\%) and S4 (AT 25\%: TUJ 15\%: TT 60\%) and repeat three times. Data from observations were analyzed using ANOVA (Analysis of Variance) at a level of 95\%, if there is a significant difference $(P>0.05)$ then a further test was performed with a DMRT (Duncan Multiple Range Test) test at a $95 \%$ significance level. The results obtained show a real effect on sensory value which includes appearance, and a very significant effect on sensory value which includes aroma and taste. The best results for sensory assessment were in the S1 treatment which had a taste value of 8.37 and a aroma of 7.82 while the best treatment for a texture of 7.26 and a crispness of 4.42 were found in the $S 1$ treatment and revealed 8.51 . The results showed a protein content of $23.75 \%$, a moisture content of $3.78 \%$ and a crude fiber content of $5.23 \%$. The results of the physical development volume test showed the best value, namely S1 treatment with a development volume value of $1.49 \%$.

Keywords: Crackers, Sardinella fish (Sardinella sp.), Ipomea batatas L, physical test, chemical test and sensory test

\section{ABSTRAK}

Tujuan penelitian ini adalah untuk mengetahui pengaruh penambahan daging ikan tembang (Sardinella sp.) dan subtitusi tepung ubi jalar putih (Ipomea batatas L.) terhadap uji fisik kimia dan sensori kerupuk ikan tembang. Penelitian ini menggunakan Rancangan Acak Lengkap (RAL) yang terdiri dari tiga perlakuan yaitu perlakuan S1(DI 25\% : TUJ 0\% : TT 75\%), S2 (DI 25\% : TUJ 5\% : TT 70\%), S3(DI 25\% : TUJ 10\% : TT 65\%) dan S4(DI 25\% : TUJ 15\% : TT 60\%) dan ulangan sebanyak tiga kali. Data hasil pengamatan dianalisa menggunakan ANOVA (Analysis of Variance) pada taraf $95 \%$, apabila terdapat beda nyata $(P>0,05)$ maka dilakukan uji lanjut dengan uji DMRT (Duncan Multiple Range Test) pada taraf nyata $95 \%$. Hasil penelitian yang diperoleh menunjukkan pengaruh nyata terhadap nilai sensori yang meliputi kenampakan, dan pengaruh sangat nyata terhadap nilai sensori yang meliputi aroma dan rasa. Hasil terbaik untuk penilaian sensori terdapat pada perlakuan S1 dimana memiliki nilai rasa 8,37 dan aroma 7,82 sedangkan perlakuan terbaik untuk tekstur 7,26 dan kerenyahan 4,42 terdapat pada perlakuan $\$ 1$ dan kenampakkan 8,51. Hasil penelitian menunjukkan kadar protein tertinggi $23,75 \%$, kadar air tertinggi 3,78\% dan kadar serat kasar tertinggi $5,23 \%$. Hasil uji fisik volume pengembangan menunjukkan nilai terbaik yaitu perlakuan $\mathrm{S} 1$ dengan nilai volume pengembangan $1,49 \%$.

Kata kunci: Kerupuk, ikan tembang (Sardinella sp.), Ipomea batatas L, uji fisik, uji kimia dan uji sensori 


\section{PENDAHULUAN}

Kerupuk merupakan makanan ringan yang sangat populer, disukai oleh banyak kalangan, baik orang dewasa maupun anak-anak. Kerupuk merupakan salah satu makanan ringan yang dikonsumsi sebagai makanan selingan atau sebagai makanan pelengkap makanan reguler. Umumnya kerupuk merupakan sumber karbohidrat sehingga diperlukan peningkatan nilai gizinya terutama kandungan protein dan serat. Kerupuk umumnya terbuat dari ikan, udang, atau tanpa campuran bahan lain. Oleh karena itu, perlu dilakukan variasi rasa dan peningkatan nilai gizi, salah satunya kerupuk yang dibuat dari campuran tepung ubi jalar putih (Ipomea batatas L.) dan ikan tembang (Sardinella sp.).

Ikan tembang (Sardinella sp.) adalah salah satu ikan pelagis kecil yang banyak dikonsumsi oleh masyarakat karena mengandung gizi yang tinggi terutama protein. Protein ikan tembang dikategorikan sebagai complete protein, yaitu memiliki kadar asam amino esensial yang tinggi. Ikan tembang merupakan makanan yang banyak vitamin dan kaya akan omega 3 yang dibutuhkan tubuh (Zainuddin et al., 2007). Umumnya, komposisi kimia daging ikan terdiri dari air 79-6\%; protein 16-6\%; lemak 2,0\% (Suratimojo, 1988) yang dapat kombinasikan dengan ubi jalar.

Ubi jalar (Ipomea batatas L.) yang dikenal di tanah air dengan warna daging umbi yang bermacammacam, diantaranya putih, kuning, jingga dan ungu. Ubi jalar merupakan tanaman yang cukup penting sebagai sumber karbohidrat setelah padi, jagung dan singkong. Kandungan terbesar dalam ubi jalar adalah karbohidrat, yang dapat dimanfaatkan sebagai sumber

\section{Rancangan Penelitian}

Penelitian ini menggunakan Rancangan Acak Lengkap (RAL) yaitu menguji pengaruh subtitusi tepung ubi jalar terhadap uji fisik kimia dan uji sensori dalam pembuatan kerupuk ikan tembang dengan mencampur antara ikan tembang, tepung tapioka dan tepung ubi jalar yang terdiri dari 4 perlakuan dengan perbandingan sebagai berikut: S1 (25\%: 0\%:75\%), S2 (25\%: 5\%:70\%), S3 (25\%: $10 \% \quad: 65 \%)$, S4 (25\%:15\%:60\%), dengan 3 kali ulangan. kalori, yang dimana kandungan karbohidrat dalam ubi jalar dapat dimanfaatkan sebagai antioksidan pencegah kanker dan beragam penyakit kardiovaskuler dan sangat baik untuk pencernaan. Ubi jalar cukup potensial sebagai bahan baku industri karena kualitasnya yang melimpah serta mudah dibudidayakan, dan memiliki kandungan protein sebesar 2,8-3,2\%, total pati 52,7-63,3\%, amilosa 16,5 $20,5 \%$, dan total gula 5,9-11,8\% (Madamba et al., 1975 dalam Sutomo 2007).

\section{METODE PENELITIAN}

\section{Alat dan Bahan}

Alat yang digunakan dalam penelitian yaitu baskom, pisau, blender, cetakan, panci, kompor, oven dan stopwatch. Alat untuk analisis proksimat dan alat untuk analisis fisik meliputi, seperangkat alat ekstraksi soxlet, gelas piala, gelas ukur, batang pengaduk, pipet tetes, pipet mikro (toppette P20), corong, tabung reaksi, labu takar, erlenmeyer, desikator, sentrifus (hettich EBAA20), timbangan analitik (matrix DJ203A), gegep, cawan porselin, dan uji fisik kerupuk paramenter yang dinilai volume pengembang.

Bahan yang digunakan pada penelitian pembuatan kerupuk ikan tembang (Sardinella sp.) dan tepung ubi jalar putih (Ipomea batatas L.), bawang putih, garam (dolpin), gula (gulaku), putih telur, dan tepung tapioka (bumi kencana). Bahan kimia untuk analisis proksimat adalah aquades, reagen biuret, larutan standar protein, alkohol 80\%, heksan, Bovin Serum Albumin, $\mathrm{NaOH}$ dan kertas saring.

\section{Pembuatan Kerupuk \\ Penyiapan Bahan Baku}

Ubi jalar Putih (Ipomea batatas L.) yang digunakan, diperoleh dari pasar Korem Kota Kendari Sulawesi Tenggara dalam bentuk buah seberat $2 \mathrm{~kg}$ dan Ikan Tembang (Sardinella sp.) yang diperoleh dari TPI Kota Kendari, Sulawesi Tenggara dalam bentuk segar sebanyak $2 \mathrm{~kg}$. 


\section{Pembuatan Tepung Ubi Jalar Putih}

Ubi jalar dikupas kulitnya kemudian dibersihkan dan diparut hingga halus, selanjutnya ditambahkan air sebanyak $1000 \mathrm{ml}$ dan disaring untuk mendapatkan pati dan ampas, lalu dikeringkan dengan menggunakan oven dengan suhu $60^{\circ} \mathrm{C}$ selama \pm 8 jam, ampas dan pati dihaluskan menggunakan blender dan diayak sehingga dihasilkan tepung ubi jalar.

\section{Pembuatan kerupuk}

Penyiapan bahan baku yaitu tepung tapioka, tepung ubi jalar putih (Ipomea batatas L.) dan ikan tembang (Sardinella sp.) dan bumbu-bumbu (bawang putih $7 \mathrm{~g}$, telur $12 \mathrm{~g}$, garam $5 \mathrm{~g}$, gula $10 \mathrm{~g}$ dan air 35 $\mathrm{mL}$ ), lalu dimasukkan ke dalam wadah dan diaduk hingga homogen. Pencetakan dengan menggunakan selongsong stainless steel dengan panjang $15 \mathrm{~cm}$ dan diameter $3 \mathrm{~cm}$, kemudian dikukus selama 2 jam dan selanjutnya dilakukan pendinginan selama 24 jam dengan suhu ruang $27^{\circ} \mathrm{C}$. Pengirisan dengan ketebalan $3 \mathrm{~mm}$ dan dikeringkan dengan sinar matahari selama 3 hari. Penggorengan dengan suhu $120^{\circ} \mathrm{C}$ selama 5 detik sebanyak 8 kerupuk.

\section{Parameter uji}

Uji Sensori (SNI. 01-2346. 2006), Uji Fisik (Volume Pengembangan Zulviani, 2000). Analisis uji kimia meliputi kadar air (AOAC, 2005), kadar protein (AOAC,2005) dan kadar serat kasar (AOAC,2005).

\section{Analisis Data}

Analisis data yang digunakan dalam penelitian ini adalah dengan menggunakan sidik ragam Analysis of Varian (ANOVA). Apabila hasil analisa terdapat perbedaan nyata, maka akan dilanjutkan dengan uji lanjut Duncan's Multiple Range Test (DMRT) pada taraf kepercayaan $95 \%(\alpha=0,05)$.

\section{HASIL DAN PEMBAHASAN}

\section{Uji sensori}

Tabel 1. Hasil analisis uji proksimat

\begin{tabular}{|c|c|c|c|c|c|}
\hline \multirow[b]{2}{*}{ Perlakuan } & \multicolumn{5}{|c|}{ Uji sensori } \\
\hline & Kenampakkan & Aroma & Rasa & Tekstur & Kerenyahan \\
\hline S1 & $8,51^{a} \pm 0,10$ & $7,82^{a} \pm 0,04$ & $8,37^{a} \pm 0,08$ & $7,26^{a} \pm 0,57$ & $4,42^{\mathrm{a}} \pm 0,04$ \\
\hline S2 & $8,22^{b} \pm 0,10$ & $7,13^{b} \pm 0,06$ & $7,31^{b} \pm 0,03$ & $6,77^{a} \pm 0,08$ & $3,71^{b} \pm 0,20$ \\
\hline S3 & $7,4^{c} \mathrm{c} \pm 0,04$ & $6,42^{c} \pm 0,04$ & $6,31^{\mathrm{c}} \pm 0,14$ & $6,55^{\mathrm{a}} \pm 0,15$ & $3,66^{b} \pm 0,11$ \\
\hline S4 & $6,46^{d} \pm 0,06$ & $5,40^{d} \pm 0,07$ & $6,09 \mathrm{~d} \pm 0,10$ & $6,59^{a} \pm 0,61$ & $3,57^{b} \pm 0,16$ \\
\hline
\end{tabular}

Tabel 2. Hasil Analisis Kandungan Kimia

\begin{tabular}{lcccc}
\hline \multirow{2}{*}{ Parameter } & \multicolumn{4}{c}{ Perlakuan } \\
\cline { 2 - 5 } & S1 & S2 & S3 & S4 \\
\hline Kadar air (\%) & 3,27 & 3,78 & 3,07 & 3,25 \\
Kadar protein (\%) & 17,71 & 18,53 & 21,25 & 23,75 \\
Kadar serat kasar (\%) & 2,69 & 3,50 & 4,84 & 5,23 \\
\hline
\end{tabular}

Tabel 3. Hasil Analisis Uji fisik

\begin{tabular}{ccc}
\hline Perlakuan & Volume Pengembangan & DMRT $_{0,05}$ \\
\hline S1 & $1,49^{a} \pm 0,10$ & \\
S2 & $0,84^{a} \pm 0,20$ & $2=88,6$ \\
S3 & $0,83^{\mathrm{a}} \pm 0,7$ & $3=84,0$ \\
S4 & $0,58^{\mathrm{b}} \pm 0,15$ & \\
\hline
\end{tabular}

Keterangan : Angka yang diikuti oleh huruf yang berbeda menunjukkan beda nyata berdasarkan uji DMRT 0,05 taraf kepercayaan $95 \%$. 


\section{Uji Sensori}

Kenampakan

Hasil uji sensori kenampakkan pada kerupuk didapatkan nilai rerata tertinggi terletak pada perlakuan S1 sebesar 8,51 dan nilai rerata terendah terletak pada perlakuan S4 sebesar 6,46. Hasil ini menunjukkan bahwa penamba han pada kerupuk mempengaruhi

nilai sensori kenampakannya. kenampakan pada kerupuk menunjukkan hasil yaitu rapi, bersih, homogen, ketebalan kurang rata, warna keputihan cerah.

Formulasi kerupuk dengan perbandingan ikan tembang dan tepung ubi jalar menghasilkan warna putih bersih. Kerupuk pada perlakuan S1 memiliki warna yang lebih terang dibandingkan kerupuk lainnya. Hal tersebut disebabkan oleh kerupuk pada perlakuan S1 yang warna yang dihasilkan menjadi lebih terang dibandingkan kerupuk lain. Hal ini dikarenakan pada ikan tembang memberikan hasil warna yang lebih terang, diketahui protein pada ikan tembang sebanyak 16,6\% (Suratimojo, 1988).

\section{Aroma}

Pengujian sensori pada kerupuk menunjukkan nilai rerata aroma kerupuk tertinggi terletak pada perlakuan $\mathrm{S} 1$ sebesar 7,82 dan nilai terendah terletak pada perlakuan S4 sebesar 5,40 . Hasil nilai uji sensori aroma pada penelitian ini sesuai dengan nilai aroma fortifikasi tepung tulang julungjulung sebagai sumber kalsium terhadap tingkat kesukaan kerupuk dari hasil penelitian Deborah et al. (2016) yaitu 7,7.

Hasil tersebut menunjukkan bahwa semakin banyak ikan tembang yang ditambahkan, semakin meningkatkan atribut aroma kerupuk maka tepung ubi jalar juga memberikan pengaruh aroma namun tidak signifikan. Aroma kerupuk yang dihasilkan secara umum masih kuat spesifik ikan dan berbanding lurus dengan atribut rasa. Menurut Setiawan et al. (2013), bertambahnya jumlah ikan yang mengandung protein dan lemak sebagai aroma ikan yang ada pada adonan membuat aroma kerupuk menjadi semakin tajam atau amis.

\section{Rasa}

Pengujian sensori terhadap rasa kerupuk menujukkan nilai rerata tertinggi pada perlakuan S1 sebesar 8,37 dan nilai terendah pada perlakuan S4 sebesar 6,09. Kerupuk perlakuan $\mathrm{S} 1$ memiliki rasa khas ikan yang lebih kuat dibandingkan kerupuk lainnya. Hal ini berkaitan dengan karakter ikan tembang sebagai bahan baku. Kerupuk pada perlakuan S1 memiliki rasa khas ikan yang lebih kuat dibandingkan kerupuk lainnya. Hal ini disebabkan karena banyaknya jumlah kosentrasi ikan tembang pada perlakuan S1 dibandingkan dengan perlakuan lainnya. Menurut pendapat Neiva et al. (2011) menyatakan bahwa seiring bertambahnya konsentrasi ikan maka rasa ikan pada produk lebih terasa. Selain itu ubi jalar juga memiliki kadar protein dan lemak yang dapat memberikan rasa umami pada kerupuk. Menurut Matanjun et al. (2009) tepung ubi jalar memiliki kadar protein dan lemak. Menurut Shizuko dan Kumiko (2000) menyatakan bahwa kadar protein dan lemak pada ubi jalar dapat menimbulkan rasa umami.

\section{Tekstur}

Hasil uji sensori menunjukkan bahwa nilai rerata tertinggi terdapat pada perlakuan $\mathrm{S} 1$ yaitu 7,26 dan rerata terendah terdapat pada perlakuan $S 3$ yaitu 6,55 . Hasil tekstur pada penelitian ini serupa dengan penelitian Ariyani dan Ayustaningwaro (2013), yang mengamati penambahan tepung duri ikan lele dumbo (Clarias gariepinus) dan tepung ubi jalar (Ipomea batatas L.) terhadap kesukaan kerupuk, dimana perlakuan F6 (0\% Tepung duri ikan lele : 25\% tepung ubi jalar) mendapatkan nilai tertinggi yaitu 4,22 dan perlakuan F1 (25\% Tepung duri ikan lele : 0\% Tepung ubi jalar) mendapatkan nilai terendah yaitu 2,60.

Kerenyahan

Kerenyahan selalu berbanding lurus dengan tekstur. Hasil uji organoleptik menunjukkan bahwa rerata nilai kerenyahan kerupuk dengan perbandingan ikan tembang dan tepung ubi jalar putih terhadap perlakuan yang diberikan dapat meningkatkan kerenyahan kerupuk. Kerupuk perlakuan S1 memiliki nilai rerata tertinggi sebesar 4,42, sedangkan kerupuk perlakuan S4 memiliki nilai rerata terendah yaitu 3,57. Hal tersebut disebabkan karna banyaknya jumlah kosentrasi ikan pada perlakuan S1 yang memiliki protein yang tinggi dibandingkan kerupuk lainnya. Menurut Istanti (2005) menyatakan kandungan protein yang tinggi dapat menyebabkan kantong-kantong udara kerupuk yang dihasilkan semakin kecil karena padatnya kantong-kantong udara tersebut terisi oleh bahan lain yaitu daging ikan yang banyak mengandung protein sehingga dapat menyebabkan 
daya kembang semakin kecil yang akhirnya dapat menyebabkan kerenyahan semakin menurun.

\section{Uji Fisik}

\section{Daya Kembang}

Hasil penelitian menunjukkan bahwa kerupuk perlakuan S1 memiliki nilai rerata tertinggi yaitu 1,49 dan kerupuk perlakuan S4 memiliki nilai rerata terendah sebesar 0,58 . Hasil ini menunjukkan semakin besar kandungan ikan yang ditambahkan dalam kerupuk menyebabkan daya kembang kerupuk menurun. Penelitian ini menghasilkan data yang tidak jauh berbeda dengan penelitian Huda et al. (2009) tentang penambahan daging ikan pora pora pada pembuatan kerupuk ikan yaitu sebesar $37.18 \%$ $107.69 \%$. Jika dibandingkan dengan daya kembang kerupuk komersial pada penelitian Huda et al. (2010) menyebutkan bahwa daya kembang kerupuk pada perlakuan sesuai dengan daya kembang kerupuk komersial. Daya kembang kerupuk komersial berada diantara 38\%-145\%. Menurut Kusumaningrum (2016) menyatakan bahwa perbedaan daya kembang menunjukan bahwa semakin banyak kandungan amilopektin dalam kerupuk ikan maka daya kembangnya akan semakin besar. Hal ini karena bangunan amilopektin kurang kompak dan kurang menahan pengembangan volume massa sebelum penggorengan. Kandungan amilopektin berasal dari tepung tapioka, oleh karena itu, semakin besar kandungan tepung tapioka dalam kerupuk ikan menyebabkan daya kembang yang semakin besar.

\section{Uji Proksimat \\ Kadar Air}

Hasil uji kadar air menunjukkan bahwa perbandingan ikan dan ubi jalar berpengaruh terhadap kadar air kerupuk, nilai rerata tertinggi terdapat pada perlakuan S2 yaitu 3,78 dan terendah terdapat pada perlakuanan S3 yaitu 3,07 . Hasil penelitian ini sesuai dengan standar SNI 01- 27132009 tentang kerupuk ikan dengan kadar air maksimal $12 \%$. Hal ini disebabkan karena kerupuk pada perlakuan S2 dan perlakuan S3 mengandung protein dan serat lebih tinggi yang berasal dari ikan dan ubi jalar yang mempengaruhi jumlah kadar air. Menurut Rizky et al. (2017) menyatakan bahwa jenis protein yang ada pada ikan dan ubi jalar mampu mengikat kadar air dalam kerupuk sehingga kadar airnya rendah. Menurut Mulyana et al. (2014), perbedaan kadar air dipengaruhi oleh kadar protein pada kerupuk.

\section{Kadar Protein}

Hasil nilai retata kadar protein pada kerupuk dengan perbandingan ikan tembang dan ubi jalar menunjukkan nilai tertinggi terdapat pada perlakuan S4 yaitu 23,75 dan terendah terdapat pada perlakuan S1 yaitu 17,71. Berdasarkan SNI (2009), kadar protein pada kerupuk minimum $6 \%$. Kadar protein terendah kerupuk hasil penelitian ini masih memenuhi standar yaitu $17,71 \%$. Kadar protein yang rendah menunjukkan kandungan sumber protein yang sedikit dalam formulasi yang digunakan dalam pembuatan kerupuk (Huda et al. 2010). Kandungan protein dalam penelitian ini lebih besar jika dibandingkan dengan kadar protein kerupuk komersial pada penelitian Huda et al. (2010) kadar protein kerupuk komersial berada dalam kisaran $5,53 \%$ sampai $16.17 \%$.

\section{Kadar Serat Kasar}

Hasil nilai retata kadar serat kasar pada kerupuk dengan perbandingan ikan tembang dan ubi jalar menunjukkan nilai tertinggi terdapat pada perlakuan S4 yaitu 5,23 dan terendah terdapat pada perlakuan $S 1$ yaitu 2,69. Hal ini dapat dikatakan bahwa ubi jalar memberi kontribusi lebih banyak untuk kadar serat kerupuk. Hasil pengujian menunjukkan bahwa rerata nilai kadar serat kasar kerupuk dengan perbandingan ikan tembang dan ubi jalar terhadap perlakuan yang diberikan dapat meningkatkan kadar serat kasar pada kerupuk. Hal ini seiring dengan peningkatan perbandingan tepung ubi jalar putih pada formulasi. Hal tersebut diduga karena tepung ubi jalar putih Ipomea batatas memiliki kandungan serat kasar yang lebih tinggi dibandingkan ikan tembang dan tepung tapioka.

\section{KESIMPULAN}

Kesimpulan dari hasil penelitian ini yaitu:

1. Terdapat pengaruh kandungan fisik kimia yang ada pada kerupuk ikan tembang. Pada perlakuan fisik S1 memiliki nilai tertinggi dengan nilai volume pengembangan $1,49 \%$, pada perlakuan kimia S4 memiliki nilai tertinggi dengan nilai kadar protein $23,75 \%$, kadar serat kasar $5,23 \%$, pada perlakuan S2 memiliki nilai kadar air yang lebih tinggi yaitu $3,78 \%$.

2. Terdapat pengaruh penambahan daging ikan tembang dan subtitusi tepung ubi jalar putih terhadap nilai sensori kerupuk. Nilai sensori berpengaruh nyata terhadap nilai kenampakan, dan berpengaruh sangat nyata terhadap aroma, 
rasa (saltness) kerupuk, tetapi berpengaruh tidak nyata terhadap uji sensori pada tekstur dan kerenyahan kerupuk.

\section{DAFTAR PUSTAKA}

Abubakar SK. Struktur dan Fungsi Kolagen. Jurnal Pelangi IImu Vol.2 No.5. 2009. HIm 21-23.

AOAC. 1995. Official Methods of Analysis. Washington: Association of Official Analytical Chemists.

Ariyani, M. dan Ayustaningwarno, F. (2013) "Pengaruh Penambahan Tepung Duri lkan Lele Dumbo (Clarias Gariepinus) Dan Bubur Rumput Laut (Eucheuma Cottonii) Terhadap Kadar Kalsium, Kadar Serat Kasar Dan Kesukaan Kerupuk," Journal of Nutrition College, 2(1):223-231.

Badan Standarisasi Nasional. 2006. Cara Uji Organoleptik Pada Produk Perikanan. SNI,012346.2006.

Badan Standarisasi Nasional. 2009. Kerupuk Udang. SNI 01-2714-2009.

Deborah, Tabita., Afrianto., Eddy.,Pratama.,R.I. 2016. Fortifikasi Tepung Tulang Julung-Julung Sebagai Sumber Kalsium Terhadap Tingkat Kesukaan. Jurnal Perikanan Kelautan Vol. VII No. 1 /Juni 2016 (48-53).

Huda, N., A.L. Leng., C.X. Yee., dan Herpandi. 2010. Chemical Composition, Colour and Linear Expansion Properties Of Malaysian Commercial Fish Cracker (Keropok). Asian Journal Food Agro-Industry, 3(5):473-482.

Huda, N., I. Boni., dan I. Noryati. 2009. The Effect Of Different Ratios Of Dory Fish To Tapioca Flour On The Linear Expansion, Oil Absorption, Colour And Hardness Of Fish Crackers. International Food Research Journal 16: 159165.

Istanti, I. 2005. Pengaruh Lama Penyimpanan Terhadap Karakteristik Kerupuk Ikan Sapusapu. Skripsi. Fakultas Perikanan dan IImu Kelautan, IPB. Bogor.

Jose M E, Marina C, Alberto S. C. The System of Low-Molecular-Weight Carrageenans and Agaroids from The Room-TemperatureExtracted Faction of Kappaphycus alvarezii. Carbohydrate Research. 325 (2000) 287-299

Kusumaningrum, I. 2009. Analisa Faktor Daya Kembang dan Daya Serap Kerupuk Rumput Laut pada Variasi Proporsi Rumput Laut
(Eucheuma cottonii). Jurnal ISSN 1858-2419 Vol. 4, No. 2.

Matanjun, Patricia., Mohamed, Suhaila., Mustapha, Noordin., Muhammad, Kharidah. Nutrient content of tropical edible seaweeds, Eucheuma cottonii, Caulerpa lentillifera and Sargassum polycystum. J Appl Phycol (2009) 21:75-80.

Mulyana., W.H. Susanto., dan I. Purwantiningrum. 2014. Pengaruh Proporsi (Tepung Tempe Semangit: Tepung Tapioka) dan Penambahan Air Terhadap Karakteristik Kerupuk Tempe Semangit. Jurnal Pangan an Agroindustri, 2(4): 113-120.

Neiva, C.R.P., T.M. Machado., R.Y. Tomita., E.F. Furlan., M.J.L. Neto., dan D.H.M. Bastos. 2011. Fish Crackers Development From Minced Fish And Starch: An Innovative Approach To A Traditional Product.

Rika, S. 2013. Prospek Tepung Sukun Untuk Berbagai Produk Makanan Olahan dalam Upaya Menunjang Divertifikasi Pangan. Makalah Pribadi pengantar ke Falsafah Sains. Program Sarjana S3. Institut Pertanian Bogor. Bogor.

Rizky, Dinda., Sumardianto., Wijayanti I. 2017. Perbandingan Penambahan Ikan Teri (Stolephorus sp.) dan ubi jalar unggu Ipomea batatas L Terhadap Kadar Kalsium, Serat Kasar, dan Kesukaan Kerupuk Ikan. Vol. 6 No. 1 Th. 2017.

Setiawan, G., Rusmarilin H., dan Ginting S. 2013. Studi Pengaruh Zat Pengembang dan Penambahan Ikan pada Pembuatan Kerupuk Ikan Ubi Jalar. Jurnal Rekayasa Pangan dan Pertanian, 1 (2): hal

Suratimojo, A., 1988. Pengaruh Enzim Bromelin dan Lama Pemeraman Terhadap Perubahan Protein Daging ikan Tembang (Sardinella fimbriata). UNSRAT Manado.

Sutomo, B. (2007). Ubi Merah Cegah Kanker \& Kaya Vitamin A. http://budiboga.blogspot.com/2007/06/ jangan-salah-pilih-inilah-ubijalar. html. [20 Mei 2009].

Shizuko $\mathrm{Y}$ dan Kumiko N. Umami dan Kelezatan Makanan. Journal of Nutrition 2000; 130: 921S-926S.

Winarno, F. G. 2004. Kimia Pangan dan Gizi. PT Gramedia Pustaka Utama. Jakarta. $235 \mathrm{hlm}$. 
Zainuddin, M., Safruddin, dan Ismail. 2007. Zulfahmi AN, Swastawati F, Romadhon. 2014. Pendugaan Potensi Sumberdaya Laut dan Migrasi Ikan Pelagis Kecil di Sekitar Perairan Pemanfaatan daging ikan tenggiri Jeneponto. Laporan Hasil Penelitian. (Scomberomorus commersoni) dengan Laboratorium Sistem Informasi Perikanan konsentrasi yang berbeda pada pembuatan Tangkap. Program Studi Pemanfaatan kerupuk ikan. Jurnal Pengolahan dan Sumberdaya Perikanan. Jurusan Perikanan. Bioteknologi Hasil Perikanan 3(4):133-139. Fakultas IImu Kelautan dan Perikanan. Universitas Hasanuddin. Makassar. 